\title{
Legeetikk og ytringsfrihet
}

\author{
Legers rett til å ytre seg fritt er gjenstand for stor offentlig debatt. To saker behandlet i Rådet for legeetikk \\ nyanserer legers forhold til offentligheten. Leger oppfordres til å delta i offentlig debatt om medisinske \\ spørsmål og om kritikkverdige forhold i helsetjenesten.
}

Karsten Hytten

karsten@hytten.no

Ytringsfriheten er hjemlet i Grunnloven $\S 100$. Den er tradisjonelt begrunnet i tre hensyn: kun ved fri meningsutveksling kan man komme nærmere sannheten i en sak, ved å dele autonome, frie tanker og ta imot andres, utvikles vi som mennesker, og endelig at demokratiet hviler på at frie ytringer bidrar til fri meningsdannelse (1).

Rådet for legeetikk får med jevne mellomrom klager på legers ytringer. Klagene kommer fra andre leger, fra pasienter og fra publikum (2). I de etiske reglene for leger er det særlig følgende utdrag som retter seg mot legers ytringer (3) (min understrekning):

Kap. I, § 9: «(...)Legen må ikke gjøre bruk av eller anbefale metoder som savner grunnlag $i$ vitenskapelige undersøkelser eller tilstrekkelig medisinsk erfaring(...).»

Kap. I, § 11: «En lege bør etter sine forutsetninger medvirke til at almenheten og myndigheter fär saklig informasjon om medisinske sporsmål. En lege som avgir uttalelse om medisinske spørsmål, bør sikre seg adgang til å kontrollere hvordan uttalelsen blir offentliggjort.»

Kap. II, § 4: «En lege må vare varsom med å kritisere kolleger og medarbeidere overfor pasienter og pårørende, men må alltid ha pasientens interesse for øye.»

Kap. II, § 5: «Offentlig og annen debatt mellom kolleger $i$ medisinske og helsepolitiske spørsmål skal holdes på et saklig plan.»

I tillegg har de etiske reglene et eget kapittel III om markedsføring og annen informasjon om legevirksomhet som også kan betraktes som ytringer. Disse reglene er strenge og innebærer bl.a. at legers markedsføring kun skal inneholde nøktern informasjon om virksomheten.

Rådet har nylig behandlet to klager som belyser forholdet mellom legeetikk og ytringsfrihet. De gjengis i det følgende.

\section{Klage på kronikk}

En lege hadde skrevet en kronikk i forbindelse med en pågående offentlig debatt om langvarig behandling av antatt borreliose. Klager mente at kronikøren var respektløs og harselerende overfor en gruppe syke mennesker. Innklaget lege påpekte $\mathrm{i}$ sitt tilsvar at han ikke hengte ut enkeltpasienter eller betvilte at de var syke, men at han imøtegikk offentlige ytringer som han mente stred med dokumenterte oppfatninger internasjonalt, bl.a. for å forhindre en utbredt bruk av langvarige antibiotikakurer på udokumentert grunnlag.

Rådet mente at diskusjonen om diagnose, konsekvens og behandling av borreliose er en meget viktig medisinskfaglig debatt, der det medisinske miljøet utfordres. Nettopp derfor mente Rådet at det var viktig og riktig at legen engasjerte seg i debatten for å synliggjøre og dokumentere begrunnelsene for de gjeldende retningslinjene. Rådet mente at kronikken var saklig og faglig begrunnet, og at det var akseptabelt at den hadde en spisset form, ikke minst fordi den aktuelle debatten var blitt ført i en spisset form. Rådet var i sin vurdering også opptatt av at legens ytringer var velegnet til å imøtegås i en offentlig debatt, slik nettopp ytringsfriheten inviterer til.

\section{Klage på uttalelse i mediene}

Den andre saken gjaldt en leges offentlige uttalelser i mediene. I en avis kom det frem at en dommer var mistenkt for fyllekjøring og at han fikk sykepenger til tross for at han var innvilget avskjed fra stillingen. Innklaget lege uttalte til avisen at dette var et grotesk eksempel på misbruk av sykepengeordningen og statens midler, og at det offentlige, siden situasjonen var selvforskyldt, ikke skulle sikre vedkommende med sykelønn. Pasientens arbeidsgiver imøtegikk innklaget leges fremstilling i samme avis. Klager, som var dommerens lege, mente innklaget lege hadde uttalt seg om en persons helsetilstand og konkludert med at tilstanden var selvforskyldt uten selv å ha undersøkt pasienten, og at han beskrev dommeren som trygdemisbruker. Klager hadde også bedt Fylkesmannen om å vurdere om det i denne saken var misbruk av sykepengeordningen og statens midler, noe Fylkesmannen ikke fant grunn til å gå videre med.

Rådet mente at det var prisverdig at innklaget lege reiste spørsmål om bruk og misbruk av sykepengeordningen, men var kritisk til måten han hadde gjort dette på. Rådet mente at han uttalte seg konkret og kraftfullt om en sak han ikke kjente detaljene i, med kraftig kritikk av både sykmeldende lege og sykmeldt pasient som konsekvens. Videre mente Rådet at innklaget lege i denne saken burde reservert seg mot å uttale seg om den aktuelle saken fordi han ikke hadde tilstrekkelig kunnskap om den, og heller tatt til orde for en kritisk debatt om sykmeldingspraksis i saker der mennesker har havnet i vanskelige situasjoner.

\section{Ansvar for offentlig debatt}

Generelt mener Rådet for legeetikk at det skal mye til for å kritisere legers ytringer. Vi oppfordrer leger til å delta i den offentlige debatten om medisinske og helsepolitiske spørsmål. Særlig viktig er dette i dagens tabloide medieverden der oppslag om helsespørsmål ofte tas ut av en større sammenheng og får urimelige dimensjoner. Det er egnet til å skape alvorlig, unødvendig helseangst i befolkningen. Imidlertid skal legers innspill være saklige, og Rådet oppfordrer leger til å unngå en tone som er harselerende både fordi det kan oppleves krenkende og fordi det kan svekke budskapet.

\section{Legers ytringer $\mathrm{i}$ arbeidsforhold} Det pågår kontinuerlig en viktig debatt om organiseringen og styringen av helsevesenet der leger er sentrale bidragsytere. Som nevnt i de etiske reglene for leger, kap. I, $\S 11$, bør leger medvirke til at myndigheter og publikum får informasjon om sentrale medisinske spørsmål. Dette vil innebære at det tidvis er riktig av leger også å ta opp og informere offentligheten om kritikkverdige forhold på arbeidsplassen når intern informasjon ikke har ført frem. Etter helsepersonelloven $\S 17$ har helsepersonell plikt til å gi opplysninger til tilsynsmyndighetene om forhold som kan medføre fare for pasienters sikkerhet. Videre følger det av arbeidsmiljøloven $\S 2-4$ første ledd at arbeidstaker har rett til å varsle om kritikkverdige forhold i virksomheten (4).

Legers ytringsfrihet $\mathrm{i}$ arbeidsforhold er primært begrenset av taushetsplikten. I tillegg vil arbeidsgivere ofte henvise til 


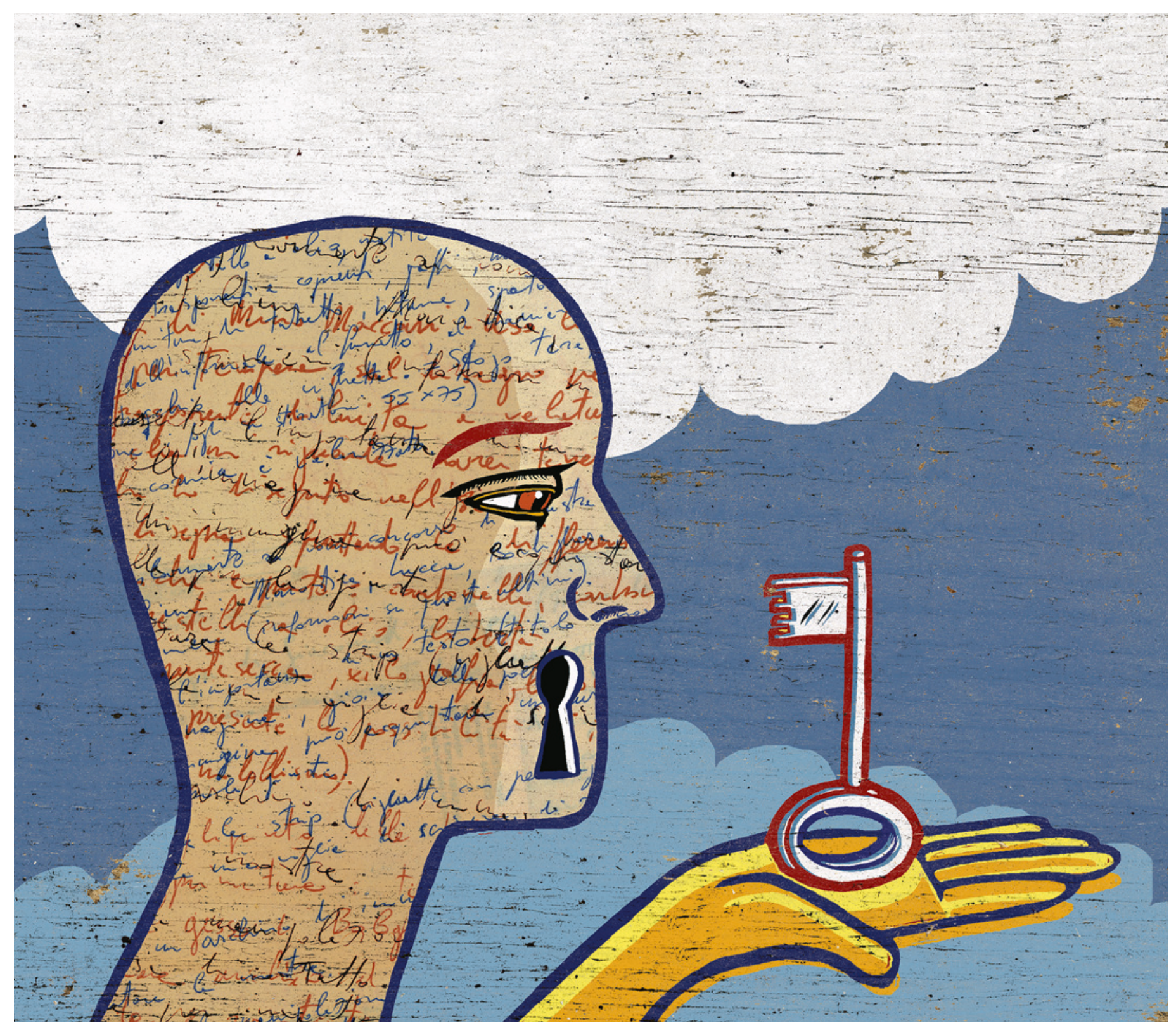

Illustrasjon: Corbis

legers lojalitetsplikt når ytringer er kritiske til virksomheten. Samtidig er det krav om offentlighet $i$ offentlige tjenester, og lojalitetsplikten gjelder også overfor allmenheten som leger er satt til å betjene. Leger har som nevnt rett til å varsle om kritikkverdige forhold. Imidlertid er det i loven anført at varslingen skal skje på en forsvarlig måte. Dette forsvarlighetskravet er en videreføring av den ulovfestede lojalitetsplikten ansatte har overfor arbeidsgiver $(5,6)$.

Nylig arrangerte norsk PEN et seminar om varslere i helsevesenet (7). Her kom det frem flere skremmende historier der varslere var blitt møtt med svært alvorlige negative sanksjoner med store personlige omkostninger - primært fra arbeidsgiver - på bakgrunn av varsling (8).
Rådet ser med bekymring på den beskrevne utviklingen. En god utvikling av helsevesenet, både for pasienter og pårørende, helsepersonell og politikere, forutsetter åpenhet og tillit og en offentlighet der ytringer kan brynes mot hverandre.

\section{Karsten Hytten (f. 1953)}

er dr.med., spesialist i psykiatri og medlem av Rådet for legeetikk fra 2006.

Forfatter har fylt ut ICMJE-skjemaet og oppgir ingen interessekonflikter.

\section{Litteratur}

1. Syse H. Det vi sier til hverandre. Om tanke, tale og toleranse. Oslo: Cappelen Damm, 2015.
2. Hytten K. Leger og ytringsfrihet. Tidsskr Nor Legeforen 2008; 128: 2367.

3. Etiske regler for leger: http://legeforeningen.no/ Om-Legeforeningen/Organisasjonen/ Rad-og-utvalg/Organisasjonspolitiske-utvalg/ etikk/etiske-regler-for-leger/ (9.3.2016).

4. Befring AK, Ohnstad B. Helsepersonelloven - med kommentarer. Oslo: Fagbokforlaget, 2010.

5. Jakhelln H. Legers ytringsfrihet. Tidsskr Nor Legeforen 2002; 122: 1038-9.

6. Befring AK. Ytringsfrihet i arbeidsforhold. Tidsskr Nor Legeforen 2014; 134: 1168-9.

7. Norsk PEN. Opptak fra seminaret «Hvem beskytter varslerne i helsevesenet?» http://norskpen.no/ 2016/02/15/opptak-fra-seminaret-hvembeskytter-varslerne-i-helsevesenet/ (3.3.2016).

8. Berg E. Hold munn eller gå. Makt og avmakt i helsevesenet. Oslo: Emilia forlag, 2015. 